\title{
A Study of the Furocoumarin Derivative of Ruta Chalepensis L. (Rutaceae)
}

\section{Ekbal H.AL-Khateeb, Ali A. AL-Shamma, Bajes A. Nehar Received 2-3-2002 Accepted 23-10-2002}

\section{ABSTRACT}

The content of Furocoumarin derivatives (Psoralens) of Ruta Chalepensis L. (Whole plant) was studied by simple extraction with petroleum ether (b.p. $60-80 \mathrm{C}^{\mathrm{o}}$ ). The results indicated that the plant contains a total of about $(0.015 \%)$.

Investigation of these compounds by thin layer chromatography (TLC) revealed the presence of at least four compounds of which methoxsalen (8-methoxypsoralen) was isolated. It was identified and authenticated with a standard by spectral method, IR, NMR, Mass spectra and HPLC.This plant could be considered as a good source for supplying this compound, which is widely used in dermatological preparations.

الخلاصة

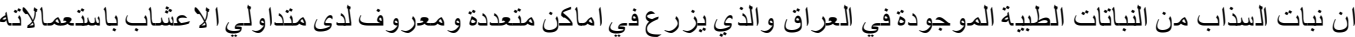

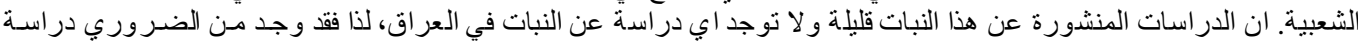

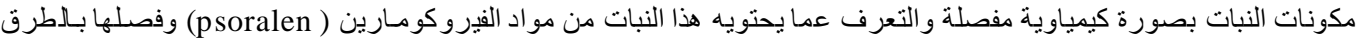

المتبعة.

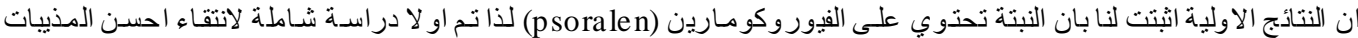

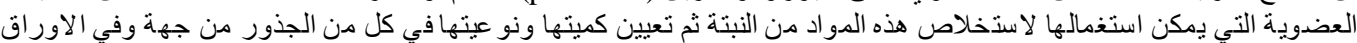

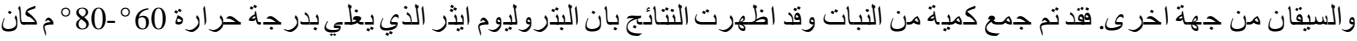

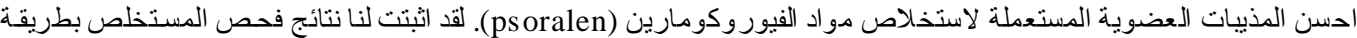

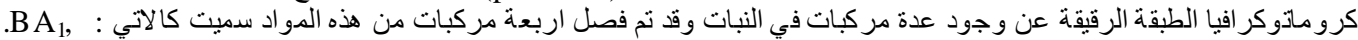

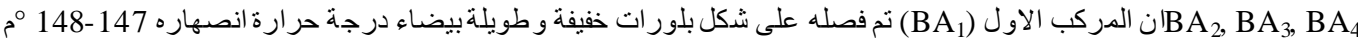

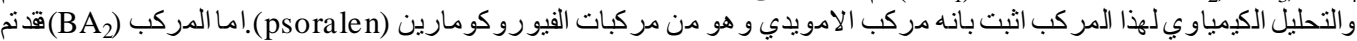

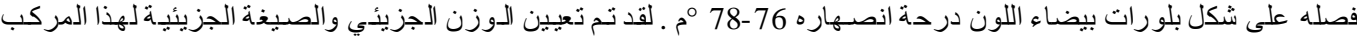

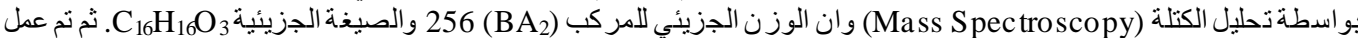
NMR و و لهذا المر كب لتحديد الشكل الكيمياوي لهذ المركب ، حيث و جد من خلال هذه التحاليل ان المركب (BA

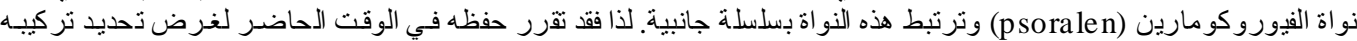
الكيمباوي في المستقبل القريب.امـا المركب (BA3

\section{INTRODUCTION}

Ruta Chalepensis L. (Rutace ae) is a cultivatec plant ${ }^{[1]}$ widely grown as garden ornamentals in Baghdad and its vicinity. Ruta, Rue and Sadhab are common names for this plant.

Rutaceae (also termed Rue family) is one of the important families, that comprises many genera and species which have been used as a source of drugs and medicines ${ }^{[2]}$. The decoction of this plant has been used in folk remedy as carminative to cure stomach ache in children $^{[3]}$.

This study was carried in connection with a program of using the chemical constitutes of Iraqi Medicinal Plants as a potential for industrial purposes. Literature survey revealed that Ruta chalepenis L., contains many important components ${ }^{[3-9]}$, among which are coumarins and Furocoumarin derivatives.Since no previous work has been done on this Iraqi plant was found that study of these compounds, is of advantage for its economical value and uses in dermatological preparations, as available imported ones are very expensive.

\section{MATERIALS and METHOD}

The plant material was collected during September and October 1997 from the gardens of the vicinity of the city of Baghdad. Four and a half kilograms of powdered plant material (aerial plants and roots) were extracted with 12 liters of petroleum ether (b.p. 60-80 $\mathrm{C}^{\mathrm{o}}$ ), under reflex for 72 hours. The petroleum ether extract was filtered and evaporated to dryness, under reduced pressure at a temperature not exceeding $40 \mathrm{C}^{\mathrm{o}}$, leaving a dark green residue (80 gm). 


\section{Separation and Fractionation of Furocoumarin Derivatives:}

Different partition processes together with column chromatography technique were tried but with unsuccessful results. So the separation and fractionation was carried by using preparative this layer chromatography.

A quantity of $20 \mathrm{gm}$ of the residue was dissolved in a minimum amount of chloroform and applied together with standard psoralen reference compounds (methoxsalen and imperatorin) on a number of preparative TLC plates of silica gel GF254 (0.75 mm thickness) and developed with solvent system benzeneacetone $(90: 10 \mathrm{v} / \mathrm{v})$.

The developed plates were visualized under U.V light (366 nm wavelength). Four major bands were observed and designated as band I, II, III and IV.

Band II and III were overlapped, and both have very close $R_{f}$ values to that of the standard reference methoxsalen.

These two bands were separated by multiple development using the same solvent system to give two compounds.

Band I gave compound I as yellowish crystals $(25 \mathrm{mg})$ upon recrystallization out of boiling methanol, a fluffy colorless crystals was obtained $(20 \mathrm{mg})$ having a sharp melting point of $147.5^{\circ}$. Out of band II, compound 2 was isolated as yellowish prismatic crystals (125 mg), upon recrystallization out of hot petroleum ether (b.p. 60-80 $\mathrm{C}^{\mathrm{o}}$ ) a colorless long prismatic crystals $(120 \mathrm{mg})$ was obtained having a sharp melting point of $78 \mathrm{C}^{\circ}$.

Out of band III, compound 3 was is olated as a yellowish crystals $(2.7 \mathrm{mg})$ upon recrystallization out of boiling ethanol fluffy like crystals $(2.5 \mathrm{mg})$ was obtained.

Out of band IV, compound 4 was isolated as an oily material. The total yields of these compounds isolated from the total extract $(80$ gm)- were: $80 \mathrm{mg}$ of compound $1 ; 480 \mathrm{mg}$ of compound $2 ; 10 \mathrm{mg}$ of compound 3 ; and oily material designated as compound 4 .

\section{RESULTS and DISCUSSION}

Out of these compounds, only compound 1 was identified and confirmed to be methoxsalen (xanthotoxin) as it has similar melting point, $\mathrm{CH}$ analysis, and $\mathrm{R}_{\mathrm{f}}$ values in different solvent systems with standard reference of methoxsalen.

An assay by HPLC also was done for compound 1, using methoxsalen U.S.P. $1 \%$ as a standard reference. The retention time was exactly the same, further identification was carried out by enrichment technique, in which the reference was added individually to compound 1, using three different mobile phases (Fig. $1_{a}, b, c$ ).
Other spectral methods were used for further confirmation. The mass spectrum of compound 1 indicates a molecular ion peak at m/e 216 . The fragmentation pattern showing significant peaks as shown in (Fig. 2). The NMR spectrum in $\mathrm{CDCl}_{3}$ (Fig. 3) confirmed the presence of eight protons. The proton $\left(\mathrm{H}_{4}\right)$ and $\left(\mathrm{H}_{5}\right)$ as two doublet at $\delta 6.8\left(\mathrm{H}_{4}\right)$ and $\delta 7.71\left(\mathrm{H}_{5}\right)$ (shielded $(\mathrm{J})$ is small as expected for the furor $\operatorname{ring}(\mathrm{J}=1$ $2 \mathrm{Cps})) .\left(\mathrm{H}_{3}\right)$ proton showed singlet peak at $\delta$ 7.82 (aromatic proton) $\left(\mathrm{H}_{1}\right)$ and $\left(\mathrm{H}_{2}\right)$ protons also appeared as tw o doublet peaks at $\delta 7.35, \delta$ 7.26 for $\left(\mathrm{H}_{1}\right)$ proton, at $\delta 6.43$ and $\delta 6.31$ for $\left(\mathrm{H}_{2}\right)$ proton. Methoxy group protons showed at $\delta$ 4.3. The IR spectrum (KBr) (Fig. 4) confirms the structure. $\mathrm{C}=\mathrm{O}$ stretching band at 1575 $\mathrm{cm}^{-1}$ for the $\alpha_{1} \beta$-unsaturated lactone. Two bands at $1600 \mathrm{~cm}^{-1} 1575 \mathrm{~cm}^{-1}$ for $(\mathrm{C}=\mathrm{C})$ stretching vibration of the aromatic ring. $(\mathrm{C}=$ C) alefinic band at $1660 \mathrm{~cm}^{-1}[10]$. Two bands at $1450 \mathrm{~cm}^{-1}$ and $1375 \mathrm{~cm}^{-1}$ for asymmetric bending vibration of $\mathrm{CH}_{3}$ group respectively. The stretching $\left(\mathrm{C}-\mathrm{O}-\mathrm{CH}_{3}\right)$ appe ars at $1280 \mathrm{~cm}^{-1}$ for asymmetrical stretching and $1020 \mathrm{~cm}^{-1}$ for symmetrical stretching. Two characteristic stretching vibrations for the ester function appear at $1145 \mathrm{~cm}^{-1}$ and $1090 \mathrm{~cm}^{-1}$. The moot characteristic out of plane $\mathrm{C}-\mathrm{H}$ bending vibration at $822 \mathrm{~cm}^{-1}$ and $760 \mathrm{~cm}^{-1}$. Moreover the $\mathrm{C}-\mathrm{H}$ out plane bending vibration at $870 \mathrm{~cm}^{-}$ ${ }^{1}$ is due to one free $(\mathrm{H})$ in benzene ring. Finally the out of plane olefinic $(\mathrm{H})$ (cisolefein) is present at $755 \mathrm{~cm}^{-1}$ in agreement with the structure ${ }^{[10]}$.

All the above mentioned spectral data confirmed that compound 1 is methoxsalen having the following structure:

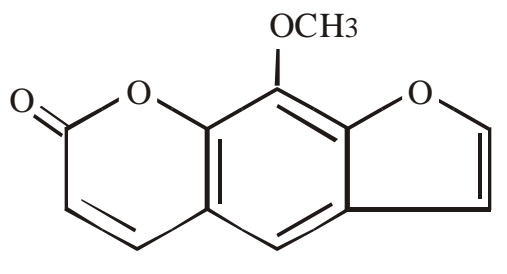

Compound 2, 3, and 4 left for further identification studies 


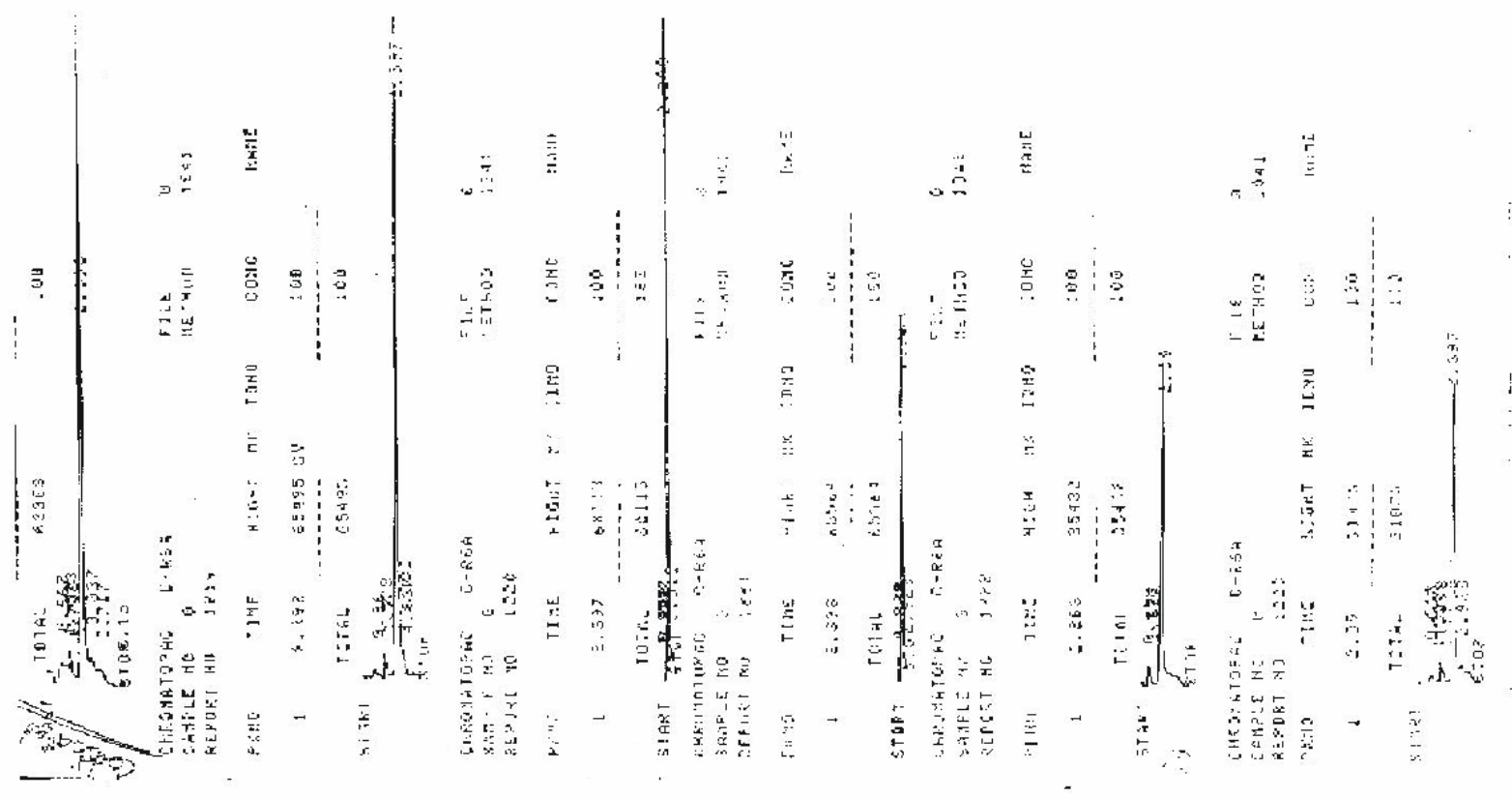

Fig $\left(1_{a}\right)$ H.P.L.C for a mixture of e qual quantities of the compound $\left(B A_{1}\right)$ and the standard reference Oxsoralon : (Methoxsalen U.S.P 1\%) with second mobile phase

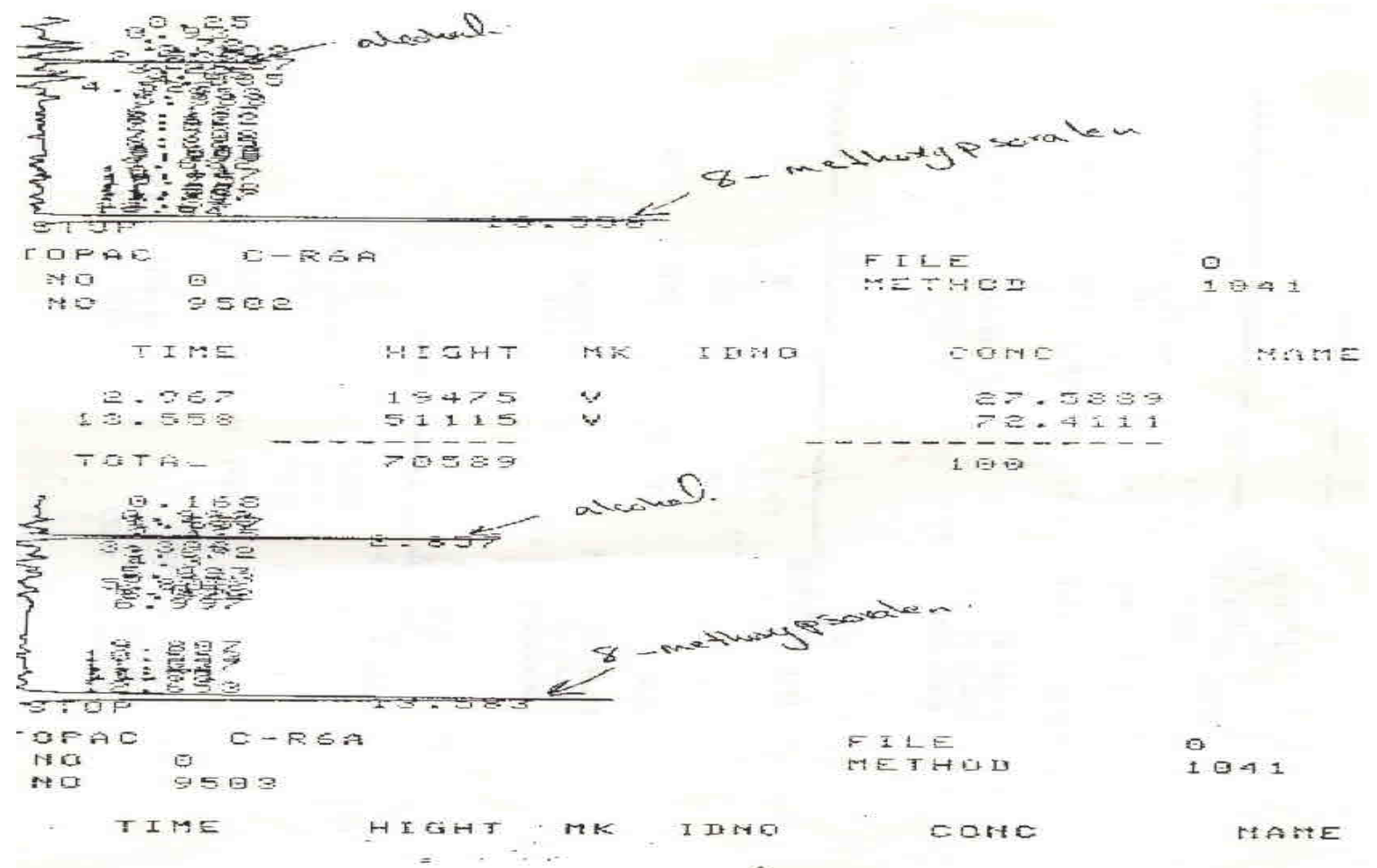

Fig (1b) HPLC for the compound $\left(\mathrm{BA}_{1}\right)$ compared to the standard reference oxsorale $n$;(Methoxsale n u.s.p $1 \%$ ) 


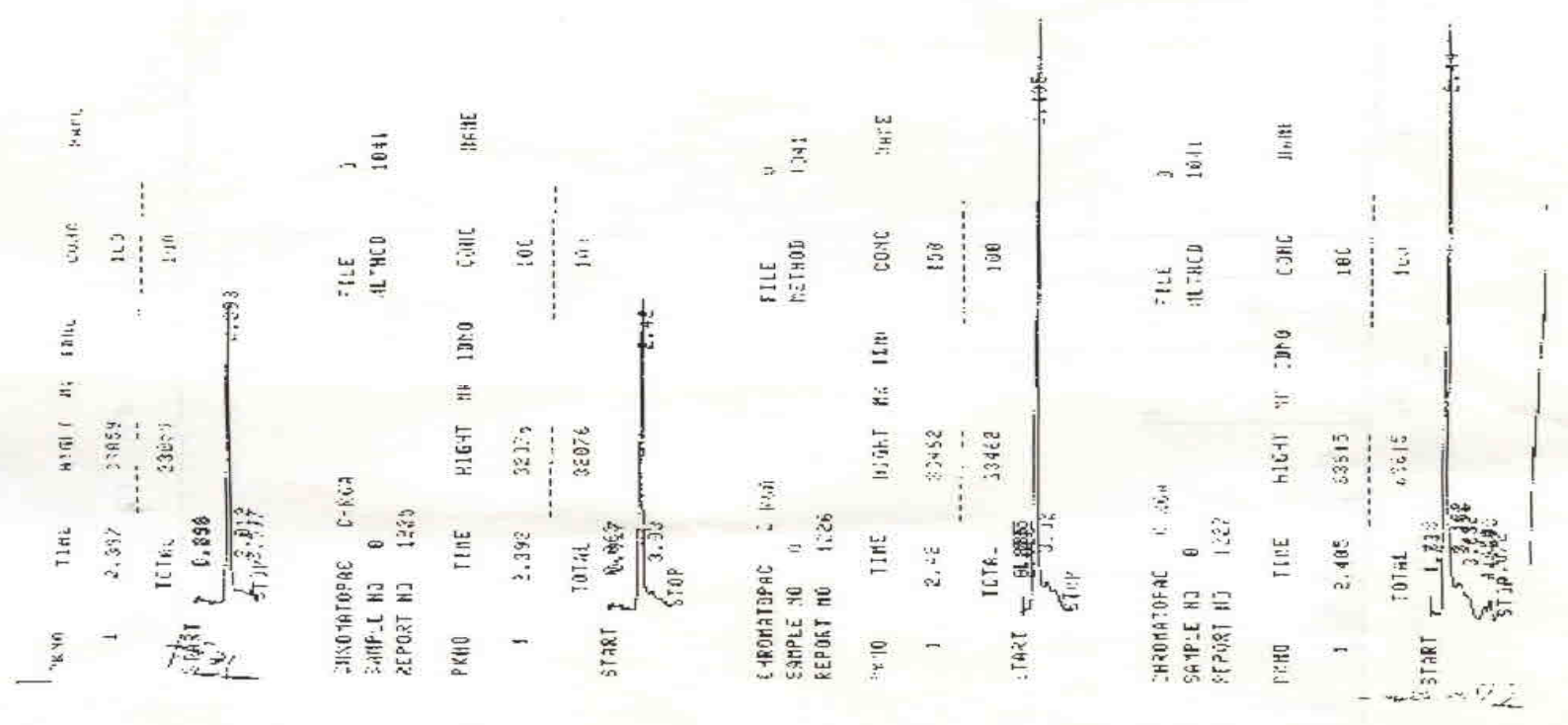

Fig.(1c) HPLC for a mixture of equal quantities of the compound $\left(B A_{1}\right)$ and the standard refe re nce Oxsoralen ; (Methoxsalen C.S.P $1 \%$ ) with third mobile phase

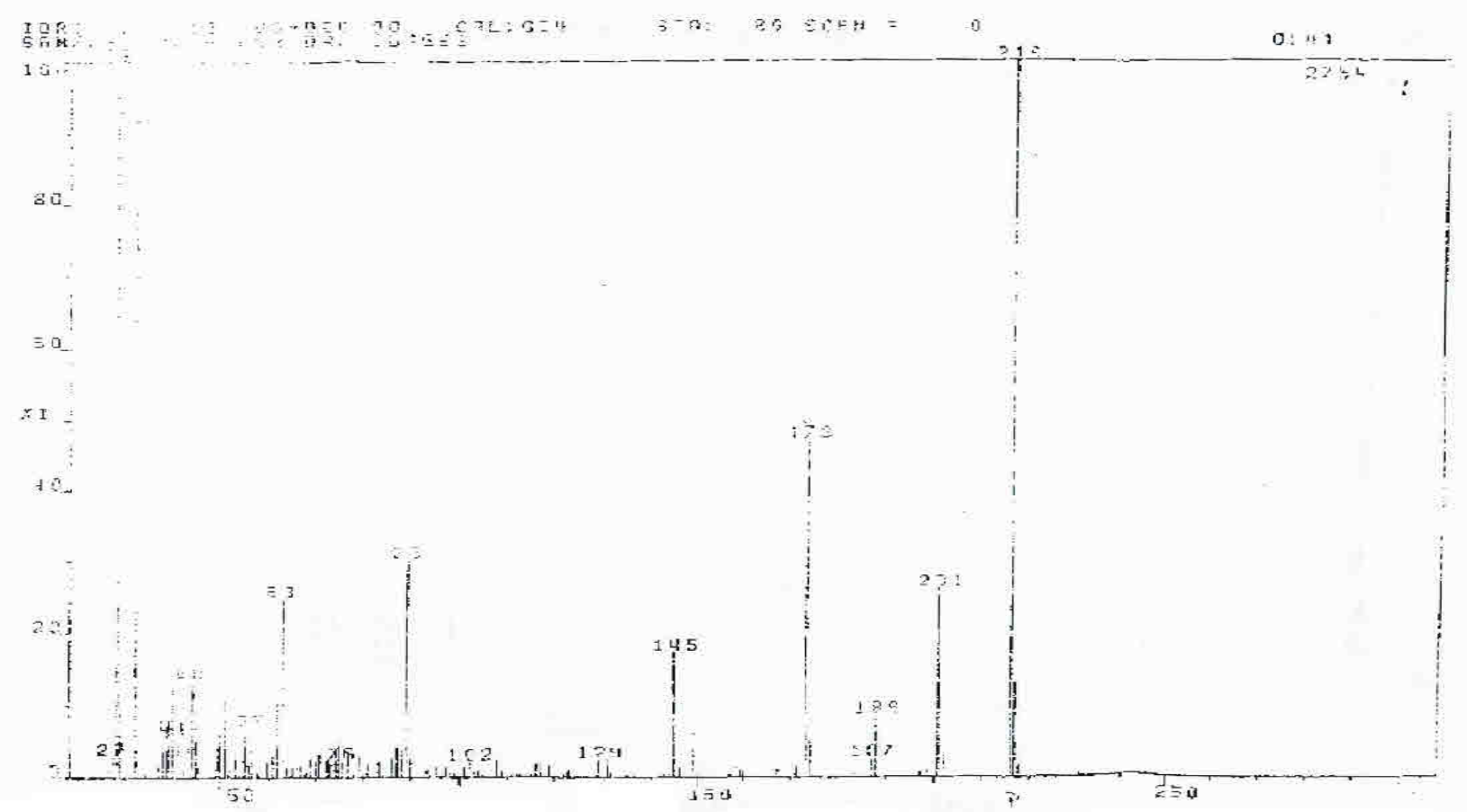

Fig (2) Mass Spectrum of the compound $\left(\mathrm{BA}_{1}\right)$ 


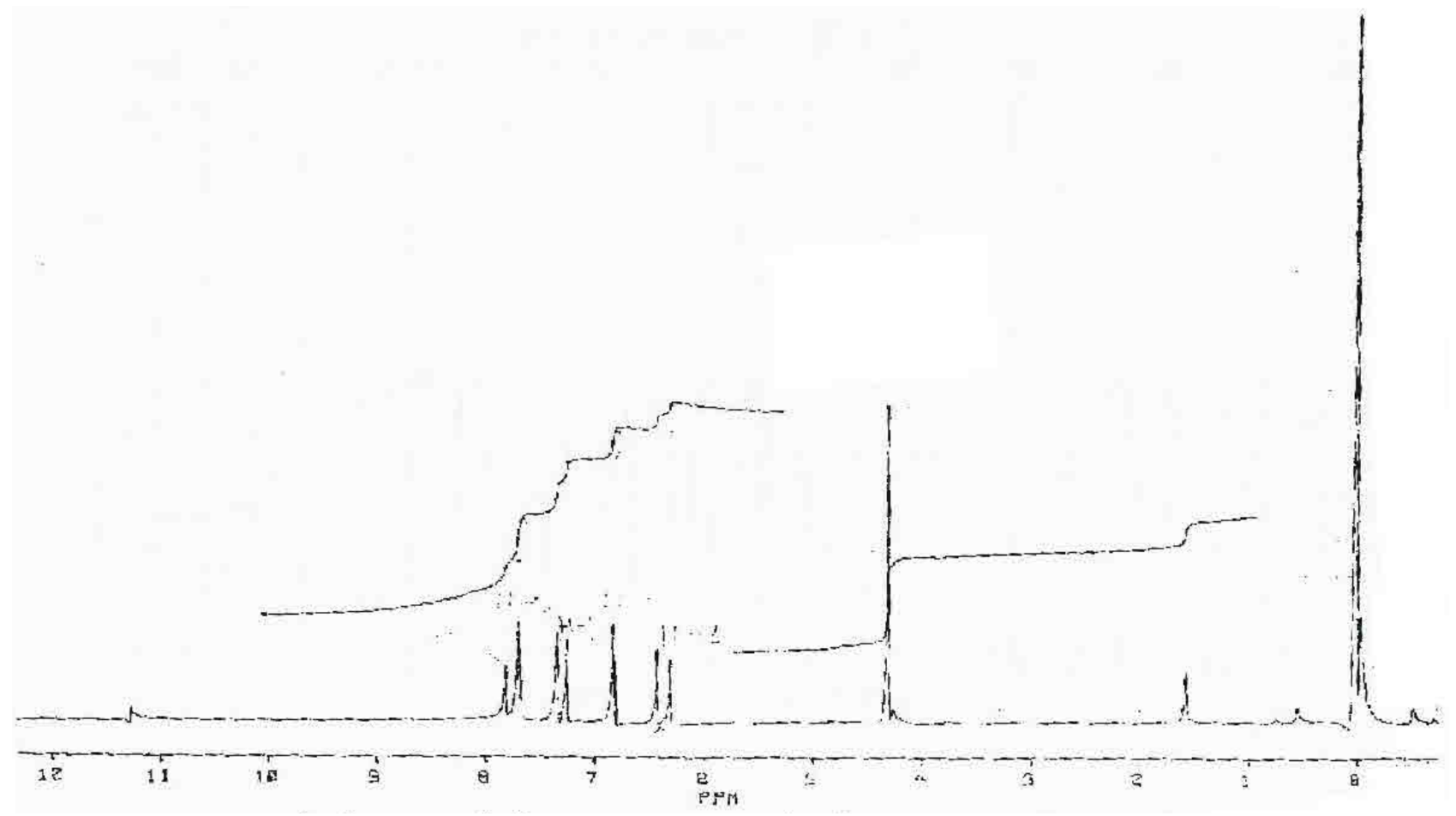

Fig (3): NMR Spectrum of the compound $\left(\mathrm{Ba}_{1}\right)$ de te rmine d in $\mathrm{CDCL}_{3}$

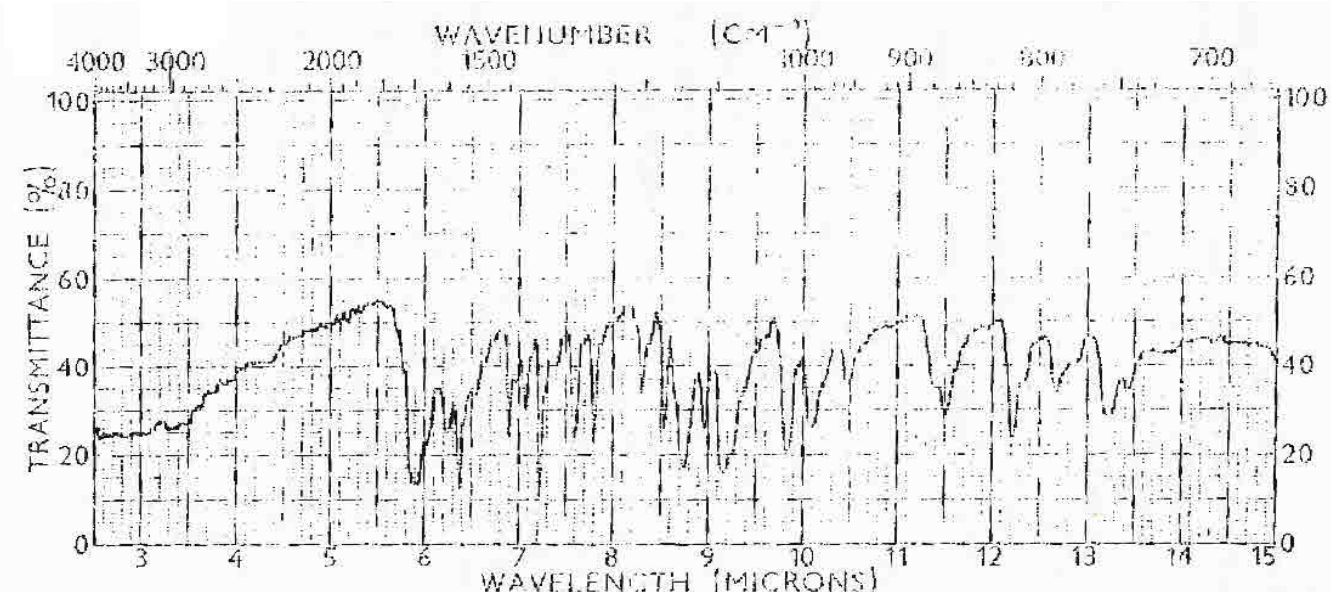

Fig (4) :IR Spectrum of compound (BA1) 


\section{REFERENCES}

1. C.C. Tounsend and Evan Guest "Flora of Iraq"., Ministry of Agriculture and Agrarian Reform, Baghdad; Republic of Iraq(1980) Vol. 4 , P. 455 .

2. Mester, I. Fitoterapia: 1973 , 44 (4). P. 123-152 .

3. El-Beih, F.K.; El-Tawil B.A.H; Baghlaf A.O. constituents of local plant. Part 12 . "Coumarins and Chalepensin a further constituents of Ruta chalepensis L.". J. Chim. Chem. Soc. (Taipi) 1981, 28 (4), 273-8 (Eng.), Via chem.. Abstr. 96, 48998r 1982.

4. Mohr N; Budzikiewicz, H; El-Tawil B.A.H; El-Beih F.K.A. constituents local plants. Part 14. "Flurther furoquinoline alkaloids from Ruta chalepensis L.". Phytochemistry, 1982, 12 (7), 1838-9 (Eng.). Via chem. Abstr. 98, 50312x (1982).

5. Ulubelen A, Terem B; Tuzlaci, E; Cheng K.F.; Kong, Y.C. "Alkaloids and coumarins from Ruta chalepensis L.". Phytochemistry 1986 ,25 (1), 2692-3 (Eng.). Via chem. Abstr. $106,135257_{\mathrm{s}} 1986$.
6. Ulubelen A, Terem B; "Alkaloids and coumarins from roots of Ruta chalepensis L.". phytochemistry 1988,27 (2), 650-1 (Eng.). Via chem. Abstr. 108, 183656j 1988.

7. Amarol, Maria Teresa; Proenca de cunha, Antonia "Linear Furocoumarins of Ruta chalepensis L.". Rev. Port.

Farm 198939 (3). 21-3 (port). Via chem. Abstr. 113, 138595f 1989.

8. Ulubelen A, Tan N; "Amoskachan from roots of ruta chalepensis L.". phytochemistry 1990 , 29(12), 3991-3 (Eng.). Via chem. Abstr. $114,225664_{s}$ (1990).

9. Ahyan Ulubelen and Husyin Guner " Isolation of Dehydro- moksachan C from Ruta chalepensis var. Iatifolia" .J. of Nat. Prod. 1988, 51, No. 5, P. 1012-1013.

10. Silverstein, Bassler and Morrill "Spectrometric identification of Organi compounds" $4^{\text {th }}$ ed. John Willy and Sons . New york 1981 , P.59-135. 